\title{
Impact of Urban Innovation on Urban Green Development in China's Yangtze River Economic Belt: Perspectives of Scale and Network
}

\author{
Feifei Tan \\ Nanjing University of Finance and Economics \\ Longxue Yang \\ Nanjing University of Finance and Economics \\ Zhaohua Lu \\ China University of Mining and Technology Beijing Campus \\ Zhiyuan Niu ( $D$ ert_new@163.com) \\ Nanjing Xiaozhuang University
}

\section{Research Article}

Keywords: Sustainable urban development, Urban green development, Urban innovation, Spatial correlation network, Yangtze River Economic Belt

Posted Date: February 7th, 2022

DOI: https://doi.org/10.21203/rs.3.rs-1259343/v1

License: (9) (i) This work is licensed under a Creative Commons Attribution 4.0 International License. Read Full License 


\section{Abstract}

Understanding whether and how urban innovation offers a sound solution to the dilemma of urban green development, is a crucial response to mitigate the detrimental effect on natural resources and environment for transitioning to sustainable urban development. To address the critical issue, we propose urban green development evaluation index system, and then examine how the urban innovation affect urban green development from the perspectives of government-scale, enterprise-scale and spatial correlation network, all of which are originally applied in the 108 cities of Yangtze River Economic Belt of China (YREB) during period 2006-2016. The evaluation results show that urban innovation promote urban green development, and both government-scale and enterprise-scale contribute to the effects. The constructed spatial correlation network of urban innovation illustrates the network structural form and reveals the network property, and further results tell that increasing network density and centrality would promote green development obviously. More specifically, the network density of urban innovation has been tied to the enhancement of urban green development, which is more significant in middle reaches than in lower and upper reaches of YREB. Similarly, optimizing the network's degree centrality and closeness centrality can help facilitate urban green development in whole YREB. Thus, the research findings would provide new insights into the essence and driving forces from various scale and hidden network when exploring and seeking urban green development path.

\section{Introduction}

In our epoch, the world has an accelerating urbanization rate and the dwellers in that more than $50 \%$ of the global population now lives in urban areas (Bloom et al., 2008), while China's gradual transition toward an urbanization-oriented development strategy leads to a spectacular socioeconomic growth and urbanization level over the past decades (Yang, 2013). As it continues along the path of rapid urbanization and industrialization, the technological innovation is the important power source to promote economic growth in China (Wang et al., 2019). In spite of its detrimental effect on natural resources, environment and social life to some degree, the technological innovation is instrumental in green development gains due to the improvement of green production and the reduction of environmental pressure continuously (Li et al., 2019; Cao et al., 2020).

The loss and degradation of natural recourse and ecological environment have raised widespread concern about the green development mode and the consequent impact to the economic activity and human well-being that they support (Tan and Lu, 2019; Ouyang et al., 2020). The green development conception has gradually gained wide currency globally. For instance, the United Nations Environment Program (UNEP) launched a "Green New Deal" and a "Green Economy" initiative through the promotion of green development in the short and medium term (Mundaca et al., 2016). Similarly, as one of China's paramount development conceptions, green development highlights the need to adhere to a national policy of resource conservation and environmental protection, and to adopt the green lifestyle and development mode. Thereby, investigating and assessing urban green development status is an essential prerequisite to improve urban or regional ecological environment (Fang et al., 2019;Weng et al., 2020; Wei et al., 2020).

With the continuous emergence of technology innovation and the concept of green development becoming more and more mature, researches on their theory and methods had been deepened. Currently, a growing body of literature has studied the interaction between urban innovation and urban green development, and various determinant analysis models have been used in the previous studies. The first strand of research focuses on the notion that urban innovation may exert a positive influence on urban green development. To be specific, innovation improves resource productivity (Pujari, 2010; Dai and Sun, 2021). Specifically, the productivity of enterprises in high-technology industries is higher than that in low-technology industries (Khanna and Sharma, 2021). Meanwhile, technological innovation can help mitigate the carbon emission risk (Liu and Zhang, 2021; Zhao et al ,2020), air pollution risk (Cui et al., 2011; Zhu et al., 2020) and other environmental risks (Chaudhry et al, 2021). It can also enhance the waste management (Li et al., 2019) and improve the resource recovery efficiency (Marchi, 2012). In addition, cities with high green development level harbors the agglomeration model of technology, capital and talents to some extent (Jin et al, 2019). Cities with low green development level should benefit from urban innovation due to higher development potential, lower technology threshold and more significant late-developing advantages (Hippel et al., 2006). The second strand of research concentrates on the negative impact of innovation on green development. For instance, the improvement of technological innovation may lead to excessive energy consumption and carbon emissions (Gunderson and Yun, 2017; Acemoglu et al., 
2012), and it is much worse for innovation due to deficient talent and capital (Jin et al, 2019). Afterwards, there may be an inverted U-shaped relationship between innovation and environmental pressure (Feng et al., 2016).

Existing studies have enlarged the research fields of urban green development, some results of which reveal that both the expansion of government-scale and enterprise-scale can enhance the driving effect from innovation on green development. The inconsistency between private cost and public cost often lead to market failure, according to the externality theory, which can be addressed from the government-scale (Glemarec and de Oliveira, 2012), such as distributing the emission rights (Guo et al, 2021; Tang et al, 2021), highlighting the role of emission tax (Villegas Palacio and Coria, 2010; Li et al, 2021), strengthening the environmental supervision (Cumming, 2007; Tang et al, 2021) and improving the green technology innovation level (Martinelli and Midttun, 2010). In the meantime, the expansion of enterprise-scale can bring the comparative advantage and talent advantage. In light of the talents advantage, for instance, the large-scale enterprises have access to more funds and preferential policies from the government (Beck et al., 2005). Subsequently, the expansion of enterprises-scale can help bring the economies of scale and economies of scope. Large-scale enterprises are more likely to implement the eco-friendly measures to improve the quality of green innovation (Wang et al, 2021), especially the state-owned enterprises. However, some studies also prove the adverse impact once expanding the scales of government and enterprise. Expanding the scale of government always increases the administrative units and rent-seeking activities, as well as the excessive bureaucracy and low administrative efficiency. Likewise, Expanding the scale of enterprise often reduce the innovation efficiency of enterprises (Mei and Shao, 2016). For example, the market full of large-scale enterprises or monopoly enterprises is more likely to be short of the competitive power to stimulate technology innovation. It is not only harmful to the sustainable technological innovation of enterprises in the market, but also destructive to the long-term health of regional market development.

Most extant studies pointed out that innovation has a positive impact on green development in virtue of technological progress (Lin and Nelson, 2017; Shao et al., 2016; Wang et al., 2019), environmental pollution migitation (Chaudhry et al, 2021; Liu and Zhang, 2021) and economic improvement (Batabyal and Beladi, 2014; Snieska and Valodkiene, 2015). But from another aspect, innovation has been identified as the drivers to improve production capacity when contributing more serious natural resource consumption as well as environmental pollution (Wang et al., 2014; Zhao et al., 2010). Despite the more and more explorations of interaction between innovation and green development, on the whole, there are scarce theoretical and practical exploration from the coupling perspectives of government-scale, enterprise-scale and spatial correlation network.

How to achieve regional multi-scale green development is key to implement the practical needs of China's current ecological civilization practice and policies and to enrich the theoretical needs of global sustainable development. To be specific, understanding whether and how urban innovation should offer a sound solution to the dilemma of urban green development, is a crucial response to mitigate the detrimental effect on natural resources and environment for transitioning to sustainable urban development. It has important implications for exploring the current institutional obstacles and policy system of urban innovation, which should be conductive to achieve urban green development effectively. Under this circumstance, this study would join the debate and presents evidence from both perspectives of scales and network when discuss about the Yangtze River Economic Belt of China.

This paper will be structured as follows: Section 2 describes data, variables and empirical models. Section 3 shows results and analysis. Section 4 gives a description for the network correlation of urban innovation and Section 5 contains main achievements, policy implications and limitations.

\section{Data And Methodology}

\subsection{Evaluation of urban green development level}

The evaluation index system of urban green development level ought to contain main influencing variables, and some principles, such as comprehensiveness, representativeness, authority and feasibility, should be taken into consideration when constructing the index system. Thereby, the index system of urban green development level in this study is characterized and identified by its economic growth, industrial structure upgrading, residents' living standards improvement and ecological 
environment management from an integrated view. Further, the modified entropy method is used to deal with index weight, and it contribute to assess the comprehensive urban green development level. Specific steps can be found in many studies (Wang et al., 2014; Tan and Lu, 2015; Tan et al., 2017), which can help maintain all information of the original samples and can help prevent the elimination of diversity of the raw data. In summary, following the sequence of 'bottom to top', each indicator is multiplied by the standardized value of each indicator with its corresponding weight, and subsequently the values of each dimension during the study period are determined to represent urban green development general trend of each city in YREB.

Table 1

Established index system of urban green development level.

\begin{tabular}{|c|c|c|c|}
\hline Dimension & Index & Weight & Attribute \\
\hline \multirow[t]{3}{*}{ Economic growth } & Per capita GDP (yuan / per capita) & 0.0577 & Positive \\
\hline & Investment in fixed assets per worker (yuan/per capita) & 0.0580 & Positive \\
\hline & Financial income per worker (ten thousand yuan/per capita) & 0.0521 & Positive \\
\hline \multirow{3}{*}{$\begin{array}{l}\text { Industrial structure } \\
\text { upgrading }\end{array}$} & Proportion of tertiary industry in GDP (\%) & 0.0661 & Positive \\
\hline & Proportion of employees in the tertiary industry (\%) & 0.0658 & Positive \\
\hline & Labor productivity of tertiary industry (ten thousand yuan/per capita) & 0.0464 & Positive \\
\hline \multirow{6}{*}{$\begin{array}{l}\text { Residents' living } \\
\text { standards } \\
\text { improvement }\end{array}$} & Disposable income of urban residents (yuan) & 0.0492 & Positive \\
\hline & Total retail sales of consumer goods per worker (yuan / per capita) & 0.0570 & Positive \\
\hline & $\begin{array}{l}\text { Urban per capita maintenance and construction capital expenditure (yuan } \\
\text { / per capita) }\end{array}$ & 0.0303 & Positive \\
\hline & Proportion of urban basic medical insurance (\%) & 0.0406 & Positive \\
\hline & Public transport vehicles per ten thousand people in the city & 0.0496 & Positive \\
\hline & Urban per capita public green space area $\left(\mathrm{km}_{2} /\right.$ per capita) & 0.0499 & Positive \\
\hline \multirow{6}{*}{$\begin{array}{l}\text { Ecological environment } \\
\text { management }\end{array}$} & Industrial $\mathrm{SO}_{2}$ removal rate $(\%)$ & 0.0621 & Positive \\
\hline & Dust removal rate of industrial smoke (\%) & 0.0655 & Positive \\
\hline & Harmless treatment rate of domestic waste (\%) & 0.0642 & Positive \\
\hline & Urban sewage treatment rate (\%) & 0.0641 & Positive \\
\hline & Per capita discharge of industrial wastewater (ton / per capita) & 0.0559 & Negative \\
\hline & Ratio of industrial solid wastes disposed and utilized (\%) & 0.0654 & Positive \\
\hline
\end{tabular}

\subsection{Urban innovation and the other variables}

The independent variable (urban innovation) is measured by the number of patent applications per capita when considering the local urban employees. The share of public expenditure in GDP stands for government-scale (threshold variable) and the log transform of total profits of industrial enterprises above designated size stands for enterprise-scale (threshold variable).

Urban green development should be affected by urban innovation, as well as by other explanatory variables. Some control variables are selected as follows. Foreign direct investment (FDI) can bring more advanced and cleaner production technology, 
and further improve the ecological environmental quality of host country, while the foreign enterprises may transfer the highpolluting industries to underdeveloped regions with low environmental standards. Environmental regulation (ER) policy can directly restrain the high pollution emission behavior of enterprises and promote the technology innovation. The government should refrain from promoting the urban green development (UGD) at the expense of a high unemployment rate (UNE). Generally speaking, with the improvement of urbanization rate (Urban), the production factors such as talents and capital are gathered in cities for improving the urban innovation level. However, the accelerating urbanization process should be harmful in the green development mode. Technology and education investment (TE) is an important driving factor for the urban green development, providing the funds and talents for urban innovation.

\subsection{Study area and data description}

As a typical region moving forward on green development demonstration belt, the Yangtze River Economic Belt (YREB) spans three regions of east, middle and west of China, and it is an important economic and population agglomeration area in China. Thereby, it is important strategic significance for transitioning to the green development model of the Yangtze River Economic Belt. In spite of seeking the common goal of the whole economic belt, there is regional heterogeneity of urban green development tendency due to different resource endowments, geographical positions, infrastructures, policy slants and so on. In particular, urban innovation is a key element for promoting urban green development. On account of the above, this paper evaluates and explores the interaction between innovation and green development from both the perspectives of scale and network.

The required data come from China Statistical Yearbook, China Industrial Statistical Yearbook, China Environmental Statistical Yearbook, China Science and Technology Statistical Yearbook, and Statistical Yearbook of Provinces and cities. Some data pretreatments should be covered. For instance, all current variables are processed and converted to the real value according to the value of 2006. Besides, taking the logarithm can help eliminate the heteroscedasticity of non-proportional and nonstandardized variables, and the linear interpolation techniques will be used once there is some missing data. Consequently, Table 2 and Table 3 show the details and descriptive statistics of main variables in this study. It should be noted that the variance expansion factor (VIF) test shows that all the selected variables do not have serious multicollinearity $(\mathrm{VIF}<10)$.

Table 2

Details of main variables.

\begin{tabular}{|c|c|c|c|}
\hline Variable & $\begin{array}{l}\text { Surrogate } \\
\text { letters }\end{array}$ & Name & Measurement methods \\
\hline $\begin{array}{l}\text { Dependent } \\
\text { variable }\end{array}$ & UGD & $\begin{array}{l}\text { Urban green } \\
\text { development }\end{array}$ & Index system calculation * 100 \\
\hline $\begin{array}{l}\text { Independent } \\
\text { variable }\end{array}$ & UINN & Urban innovation & $\begin{array}{l}\text { Patent applications per capita (piece / ten thousand yuan } \\
\text { people) }\end{array}$ \\
\hline \multirow{5}{*}{$\begin{array}{l}\text { Control } \\
\text { variable }\end{array}$} & FDI & Foreign direct investment & Proportion of foreign direct investment in GDP (\%) \\
\hline & UNE & Unemployment rate & Urban registered unemployment rate (\%) \\
\hline & ER & Environmental regulation & $\mathrm{SO}_{2}$ removal rate (\%) \\
\hline & TE & $\begin{array}{l}\text { Technology and } \\
\text { Education Investment }\end{array}$ & $\begin{array}{l}\text { Proportion of expenditure on science, technology and education } \\
\text { in total financial expenditure (\%) }\end{array}$ \\
\hline & Urban & Urbanization rate & $\begin{array}{l}\text { Proportion of permanent residents in the total population at the } \\
\text { end of the year (\%) }\end{array}$ \\
\hline \multirow{2}{*}{$\begin{array}{l}\text { Threshold } \\
\text { variable }\end{array}$} & GS & Government-scale & The proportion of public expenditure in GDP \\
\hline & ES & Enterprise-scale & $\begin{array}{l}\text { Logarithmic transformation of total profits of industrial } \\
\text { enterprises above designated size }\end{array}$ \\
\hline
\end{tabular}


Table 3

Descriptive statistical characteristics of variables.

\begin{tabular}{|lllll|}
\hline Variable symbol & Mean & Sd & Min & Max \\
\hline UGD & 100.03 & 47.839 & 39.549 & 327.770 \\
\hline UINN & 8.572 & 18.376 & 0 & 198.052 \\
\hline FDI & 2.276 & 1.958 & 0 & 11.674 \\
\hline UNE & 6.630 & 4.783 & 0 & 29.66 \\
\hline ER & 4.686 & 2.915 & -19.741 & 9.945 \\
\hline TE & 1.607 & 1.529 & 0 & 16.273 \\
\hline Urban & 5.874 & 0.977 & 2.639 & 8.923 \\
\hline GS & 0.177 & 0.094 & 0.035 & 1.485 \\
\hline ES & 4.326 & 1.424 & -2.659 & 7.977 \\
\hline
\end{tabular}

\subsection{Regression models}

The setting of the basic panel model is used to test and verify the overall impact of urban innovation (UINN) on urban green development (UGD). In addition to the urban innovation, there are some other factors to promote urban green development, such as foreign direct investment (FDI), environmental regulation (ER), unemployment rate (UNE), urbanization rate (Urban) and the Technology and Education Investment (TE). As a result, the benchmark model of urban innovation and urban green development can be established as follows.

$$
\begin{gathered}
U G D_{i t}=\beta_{0}+\beta_{1} U I N N_{i t}+\beta_{2} F D I_{i t}+\beta_{3} E R_{i t}+\beta_{4} U N E_{i t}+\beta_{5} U_{r b a n}+\beta_{6} T E_{i t}+ \\
\delta_{i}+\varepsilon_{i t}
\end{gathered}
$$

Where, $i$ stands for the individual city, $t$ represents the year, $\beta_{0}$ is the coefficient of the constant term, $\beta_{1} \sim \beta_{6}$ are the coefficients of independent and control variables, $\delta_{i}$ denotes the individual effect, and $\varepsilon_{i t}$ is the error term.

The basic panel model needs to address the endogenous problem between urban innovation and urban green development due to the deviation in coefficient estimation. Then, the solution is as follows. The fixed-effects model eliminates heterogeneity between individuals and minimizes the endogenous biases caused by the absence of variables. Here, we use a two-step System GMM for robust estimation. The GMM model of the system is presented as equation (2).

$$
\begin{gathered}
U G D_{i t}=\beta_{0}+\beta_{1} U I N N_{i t}+\beta_{2} F D I_{i t}+\beta_{3} E R_{i t}+\beta_{4} U N E_{i t}+\beta_{5} U_{r b a n}+\beta_{6} T E_{i t}+ \\
\beta_{7} U G D_{i t-1}+\delta_{i}+\varepsilon_{i t}
\end{gathered}
$$

(2)

$U G D_{i t-1}$ is the first-order lag term of urban green development level, $\beta_{7}$ is the coefficient of the lag term, and the other variables are the same as above.

In order to identify the moderating effect of government-scale and enterprise-scale, we use the threshold models to test how government-scale and enterprise-scale act on the influence process from urban innovation on urban green development. The models are set as follows. 


$$
U G D_{i t}=\beta_{0}+\beta_{1}^{\prime} U I N N_{i t}\left(G S_{i t} \leq \eta_{1}\right)+\beta_{2}^{\prime} U I N N_{i t}\left(G S_{i t} \geq \eta_{1}\right)+\delta_{i}
$$

$+\varepsilon_{i t}$

$\eta_{1}$ is the threshold value to be estimated from government-scale. This is the expression of single threshold model and so on.

$$
\begin{aligned}
U G D_{i t} & =\beta_{0}+\beta_{1}^{\prime} U I N N_{i t}\left(E S_{i t} \leq \eta_{1}\right)+\beta_{2}^{\prime} U I N N_{i t}\left(E S_{i t} \geq \eta_{1}\right)+\delta_{i} \\
& +\varepsilon_{i t}
\end{aligned}
$$

$\eta_{2}$ is the threshold value to be estimated from enterprise-scale.

\section{Results And Analysis}

\subsection{Urban green development general trend of the Yangtze River Economic Belt}

The green development level showed a steady increasing tendency for the majority of cities during period 2006-2016, while it showed a decline for a small minority of cities due to the relatively frequent eco-environmental risk accidents. Fig. 1 intuitively reflected the change characteristics of urban green development level in the Yangtze River Economic Belt in 2006, 2011 and 2016. It can be seen that there is seldom any change for most cities in Jiangsu, Shanghai and Anhui, while there is noticeable change for other cities in YREB. In particular, some cities had a high level of green development in the early period, and then they have a gradual decline in the later period. Thereby, it is of great important to explore the green development and its drivers.

\subsection{Overall impact of urban innovation on urban green development}

As presented in Table 4, the fitting degree of regression equation and the accuracy of the model will be improved once increasing the control variables gradually. According to the regression results of column (7), the current value of urban green development level and its first-order lag value tell the motivating effect. In other words, the urban innovation may accelerate the improvement of urban green development level to a certain extent. The regression results when covering other control variables verify that the regression coefficients of foreign direct investment (FDI) and unemployment rate (UNE) are significantly negative, and that of environmental regulation (ER), urbanization rate (Urban) and Technology and Education Investment (TE) are significantly positive. 
Table 4

Impact of urban innovation on urban green development in YREB.

\begin{tabular}{|c|c|c|c|c|c|c|c|}
\hline & (1) & (2) & (3) & (4) & (5) & (6) & (7) \\
\hline Variable & UGD & UGD & UGD & UGD & UGD & UGD & SysGMM \\
\hline \multirow[t]{2}{*}{ UGD } & & & & & & & $0.505^{\star \star \star}$ \\
\hline & & & & & & & $(0.168)$ \\
\hline \multirow[t]{2}{*}{ UINN } & 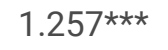 & $1.155^{\star \star \star}$ & 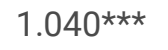 & 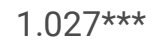 & $0.959 * \star \star$ & 0.791 ** & $0.843^{\star \star}$ \\
\hline & $(0.187)$ & $(0.205)$ & $(0.180)$ & $(0.178)$ & $(0.166)$ & $(0.158)$ & $(0.386)$ \\
\hline \multirow[t]{2}{*}{ FDI } & & $-3.037 * \star \star$ & $-2.743^{\star \star \star}$ & $-2.783^{\star \star \star}$ & $-2.975^{\star \star \star}$ & $-2.854 * \star \star$ & -1.407 \\
\hline & & (1.101) & $(0.929)$ & $(0.932)$ & $(0.904)$ & $(0.774)$ & $(0.997)$ \\
\hline \multirow[t]{2}{*}{ ER } & & & $3.170 * \star \star$ & $3.096 * \star \star$ & $2.893 * \star \star$ & $2.462^{\star \star \star}$ & $1.540 \star \star$ \\
\hline & & & $(0.766)$ & $(0.759)$ & $(0.722)$ & $(0.678)$ & $(0.672)$ \\
\hline \multirow[t]{2}{*}{ UNE } & & & & -0.451 & -0.412 & -0.337 & -0.538 \\
\hline & & & & $(0.347)$ & $(0.313)$ & $(0.258)$ & $(0.361)$ \\
\hline \multirow[t]{2}{*}{ Urban } & & & & & $6.104^{\star \star \star}$ & $6.008 * \star \star$ & 1.205 \\
\hline & & & & & $(0.844)$ & $(0.767)$ & $(1.182)$ \\
\hline \multirow[t]{2}{*}{ TE } & & & & & & 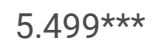 & 3.680 \\
\hline & & & & & & $(1.776)$ & (2.607) \\
\hline \multirow[t]{2}{*}{ C } & $89.25^{\star \star \star}$ & $97.04 * \star \star$ & 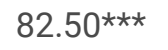 & $86.04^{\star \star \star}$ & $51.91^{\star \star \star}$ & $46.32^{\star \star \star}$ & $29.56 * \star \star$ \\
\hline & $(1.605)$ & $(3.873)$ & $(4.292)$ & $(4.889)$ & $(5.604)$ & $(5.252)$ & (8.502) \\
\hline Observations & 1,188 & 1,188 & 1,188 & 1,188 & 1,188 & 1,188 & 1,080 \\
\hline $\mathrm{R}^{2}$ & 0.395 & 0.408 & 0.482 & 0.489 & 0.515 & 0.552 & \\
\hline$N$ & 108 & 108 & 108 & 108 & 108 & 108 & 108 \\
\hline
\end{tabular}

In general, the urban innovation plays a positive and significant role in urban green development for the three urban agglomerations in the middle, lower and upper reaches of YREB from Table 5. The urban innovation in the middle reaches give the most obvious motivating effect to urban green development. To be specific, the upper reaches struggle to bring sufficient technical capital and talent investment for urban innovation, as well as the limited progress of green development level. Meanwhile, the lower reaches have a slight decline of urban innovation, leading to the impenetrable technological threshold. And there is not obvious motivating effect between urban innovation and urban green development for the lower reaches. To sum up, the urban innovation level has been tied to the enhancement of urban green development level, which is more significant in middle reaches than in lower and upper reaches of YREB. 
Table 5

Overall impact of urban innovation on urban green development in YREB.

\begin{tabular}{|c|c|c|c|}
\hline & (8) & (9) & (10) \\
\hline & Lower reaches of YREB & Middle reaches of YREB & Upper reaches of YREB \\
\hline Variable & UGD & UGD & UGD \\
\hline \multirow[t]{2}{*}{ UINN } & $1.769 * \star \star$ & $7.373^{\star \star \star}$ & 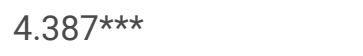 \\
\hline & $(0.338)$ & $(0.710)$ & $(0.590)$ \\
\hline \multirow[t]{2}{*}{ FDI } & 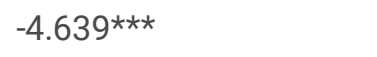 & $-3.562^{\star \star}$ & 1.806 \\
\hline & $(0.790)$ & $(1.533)$ & $(1.541)$ \\
\hline \multirow[t]{2}{*}{ ER } & 2.115 & $2.462^{\star \star \star}$ & $1.394^{\star \star}$ \\
\hline & (1.539) & $(0.609)$ & $(0.662)$ \\
\hline \multirow[t]{2}{*}{ UNE } & -0.197 & $-1.124^{\star \star}$ & -0.450 \\
\hline & $(0.189)$ & $(0.549)$ & $(0.446)$ \\
\hline \multirow[t]{2}{*}{ Urban } & 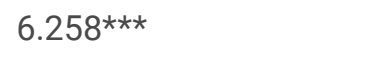 & $4.514^{\star \star \star}$ & 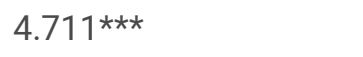 \\
\hline & $(1.068)$ & $(0.999)$ & $(1.296)$ \\
\hline \multirow[t]{2}{*}{ TE } & $6.449 * \star \star$ & 1.539 & 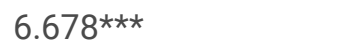 \\
\hline & $(2.225)$ & $(0.947)$ & $(2.083)$ \\
\hline \multirow[t]{2}{*}{ C } & $65.42^{\star \star \star}$ & $61.21^{\star \star \star}$ & $36.80 * \star \star$ \\
\hline & $(10.30)$ & $(9.482)$ & $(8.042)$ \\
\hline $\mathrm{R}^{2}$ & 0.613 & 0.624 & 0.474 \\
\hline$N$ & 41 & 36 & 31 \\
\hline
\end{tabular}

\subsection{From government-scale}

From the perspective of government-scale, there is a clear threshold effect between urban innovation and urban green development. The results of double-threshold model tell that there are two estimated thresholds when considering the impact of urban innovation on urban green development from government-scale, and the double threshold values are 0.094 and 0.162. According to the values, 108 cities in YREB were classified as being small-government-scale (GS $\leq 0.094)$, medium-governmentscale $(0.094<\mathrm{GS}<0.162)$ and large-government-scale $(\mathrm{GS} \geq 0.162)$. 
Table 6

Threshold effect test.

\begin{tabular}{|lllll|}
\hline Variable & & Estimate value of the threshold & F value & P value \\
\hline GS & Single threshold & 0.162 & $102.178^{\star * *}$ & 0.007 \\
\hline & Double threshold & $0.094,0.162$ & $18.112^{\star}$ & 0.06 \\
\hline & Triple threshold & 0.133 & 9.212 & 0.28 \\
\hline ES & Single threshold & 5.351 & $36.173^{\star * \star}$ & 0.030 \\
\hline & Double threshold & $2.642,5.362$ & $7.342^{\star}$ & 0.100 \\
\hline & Triple threshold & 6.609 & 5.747 & 0.265 \\
\hline
\end{tabular}

As shown in Table 7, the urban innovation plays a crucial role in promoting the urban green development level despite from various government-scales. From urban innovation to urban green development, the influence coefficient is significant in the category of large-government-scale. For example, from the angle of increasing government financial investment, cities with large government-scale often provide more financial subsidies to stimulate the innovation power of enterprises and scientific researchers, all of which will help improve the overall innovation level of the city. 
Table 7

Impact of urban innovation on urban green development under the threshold of government-scale.

\begin{tabular}{|c|c|c|c|c|c|c|}
\hline & (1) & $(2)$ & (3) & (4) & (5) & (6) \\
\hline & \multicolumn{2}{|c|}{$\mathrm{GS} \leq 0.094$} & \multicolumn{2}{|c|}{$0.094<\mathrm{GS}<0.162$} & \multicolumn{2}{|c|}{$G S \geq 0.162$} \\
\hline Variable & UGD & UGD & UGD & UGD & UGD & UGD \\
\hline \multirow[t]{2}{*}{ UINN } & 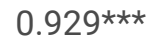 & $0.518 \star \star \star$ & $1.832^{\star \star \star}$ & 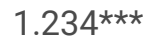 & $3.699 * \star \star$ & $3.062^{\star \star \star}$ \\
\hline & $(0.121)$ & $(0.123)$ & $(0.380)$ & $(0.292)$ & $(0.547)$ & $(0.590)$ \\
\hline \multirow[t]{2}{*}{ FDI } & & $-5.258^{*}$ & & $-2.982 * \star \star$ & & -1.907 \\
\hline & & $(2.641)$ & & $(0.883)$ & & $(2.465)$ \\
\hline \multirow[t]{2}{*}{ ER } & & 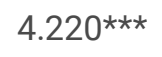 & & $2.713^{\star \star \star}$ & & 0.498 \\
\hline & & $(1.447)$ & & $(0.874)$ & & $(0.383)$ \\
\hline \multirow[t]{2}{*}{ UNE } & & -2.309 & & -0.513 & & $-0.819 * \star \star$ \\
\hline & & $(1.467)$ & & $(0.570)$ & & $(0.207)$ \\
\hline \multirow[t]{2}{*}{ Urban } & & 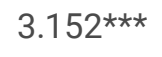 & & 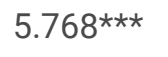 & & $2.143^{\star \star \star}$ \\
\hline & & $(1.136)$ & & $(1.121)$ & & $(0.695)$ \\
\hline \multirow[t]{2}{*}{ TE } & & 1.977 & & $3.519 *$ & & 1.603 \\
\hline & & $(1.671)$ & & $(2.050)$ & & $(2.205)$ \\
\hline \multirow[t]{2}{*}{ C } & $108.8 * \star \star$ & $103.3^{\star \star \star}$ & $86.56^{\star \star \star}$ & $47.92^{\star \star \star}$ & $0.41^{\star \star \star}$ & $65.22^{\star \star \star}$ \\
\hline & $(2.468)$ & (16.05) & $(2.984)$ & $(8.091)$ & $(1.418)$ & $(5.707)$ \\
\hline Observations & 195 & 195 & 692 & 692 & 301 & 301 \\
\hline $\mathrm{R}^{2}$ & 0.670 & 0.802 & 0.314 & 0.451 & 0.281 & 0.383 \\
\hline $\mathrm{N}$ & 48 & 48 & 98 & 98 & 50 & 50 \\
\hline
\end{tabular}

\subsection{From enterprise-scale}

From the perspective of enterprise-scale, the results tell that there is also a threshold effect between urban innovation and urban green development. The results of double-threshold model tell that there are two estimated thresholds when considering the impact of urban innovation on urban green development from enterprise-scale and the double threshold values are 2.642 and 5.362. According to the values, 108 cities in YREB were classified as being small-enterprise-scale (ES $\leq 2.642$ ), mediumenterprise-scale $(2.642<\mathrm{ES}<5.362)$ and large-enterprise-scale $(\mathrm{ES} \geq 5.362)$.

Table 8 shows the regression results after covering the threshold of enterprise-scale. The threshold effect of enterprise-scale is similar to that of government-scale. The coefficients of urban innovation are significant in the cities with various enterprise scales, suggesting that innovation-driven urban green development is effective in the cities with various enterprise scales. In particular, the influence coefficient is more significant in large-enterprise-scale than that in small and medium-enterprise-scale. Thereby, urban innovation should involve in urban green development in YREB, which is more obvious in cities with largeenterprise-scale. 
Table 8

Impact of urban innovation on urban green development under the threshold of enterprise scale.

\begin{tabular}{|c|c|c|c|c|c|c|}
\hline & (7) & (8) & (9) & (10) & (11) & (12) \\
\hline & \multicolumn{2}{|c|}{$\mathrm{ES} \leq 2.642$} & \multicolumn{2}{|c|}{$2.642<$ ES $<5.362$} & \multicolumn{2}{|c|}{$E S \geq 5.362$} \\
\hline Variable & UGD & UGD & UGD & UGD & UGD & UGD \\
\hline \multirow[t]{2}{*}{ UINN } & $0.494^{\star \star \star}$ & $0.348^{\star \star \star}$ & $0.565^{\star \star \star}$ & $0.428 * \star \star$ & $0.884^{\star \star \star}$ & $0.647 * \star \star$ \\
\hline & $(0.0737)$ & $(0.0772)$ & $(0.0958)$ & $(0.0826)$ & $(0.239)$ & $(0.204)$ \\
\hline \multirow[t]{2}{*}{ FDI } & & 0.227 & & $-2.664 * \star \star$ & & $-3.839 * * *$ \\
\hline & & $(1.034)$ & & $(0.747)$ & & $(1.435)$ \\
\hline \multirow[t]{2}{*}{ ER } & & $12.66^{\star \star \star}$ & & $5.997 * \star \star$ & & $6.767 * \star *$ \\
\hline & & $(2.264)$ & & $(1.512)$ & & $(2.309)$ \\
\hline \multirow[t]{2}{*}{ UNE } & & $-1.705^{\star \star \star}$ & & $-38.29 * \star \star$ & & $-26.40 \star$ \\
\hline & & $(0.275)$ & & $(12.44)$ & & $(13.60)$ \\
\hline \multirow[t]{2}{*}{ Urban } & & 2.273 & & $1.753^{\star \star}$ & & $4.233^{\star \star \star}$ \\
\hline & & (5.398) & & $(0.688)$ & & $(1.373)$ \\
\hline \multirow[t]{2}{*}{ TE } & & -0.0482 & & $0.205^{\star \star \star}$ & & $0.346 * * *$ \\
\hline & & $(0.135)$ & & $(0.0607)$ & & $(0.117)$ \\
\hline \multirow[t]{2}{*}{ C } & $41.48^{\star \star \star}$ & $37.58^{\star \star \star}$ & 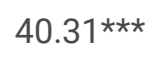 & $31.18^{\star \star \star}$ & $38.89 * \star *$ & $18.33^{\star \star}$ \\
\hline & $(0.373)$ & $(7.449)$ & $(0.249)$ & $(3.492)$ & $(0.458)$ & (7.127) \\
\hline Observations & 136 & 136 & 774 & 774 & 278 & 278 \\
\hline $\mathrm{R}^{2}$ & 0.451 & 0.658 & 0.220 & 0.432 & 0.135 & 0.425 \\
\hline $\mathrm{N}$ & 52 & 52 & 104 & 104 & 88 & 88 \\
\hline
\end{tabular}

\section{From The Spatial Innovation Correlation Network}

\subsection{Topological characteristics of spatial innovation correlation network}

The topological characteristics of spatial innovation correlation network is presented as Fig. 2. The network density and the relationship number are increasing during the study period in the network of Yangtze River Economic Belt. In terms of network density, the spatial innovation correlation network of YREB is closer and closer. However, it may include some adding redundant lines. For instance, some redundant lines should increase the transaction costs between various cities, leading to a negative impact on urban green development. Ultimately, it is critical to address how to improve the spatial correlation between cities inside YREB.

For the constructed network for 108 cities in YREB, the average value of degree centrality is 62.98 . Inside YREB, 64 cities are higher than this average value (Table 9). The degree centrality was roughly in the order of middle, upper and lower reaches. To be specific, the majority of cities are concentrated in the lower reaches and a minority of cities are distributed in the upper and middle reaches. Each city is connected with other one in the spatial innovation correlation network to a greater extent. 
The average value of closeness centrality is 6.603. Inside YREB, 57 cities are higher than the average value (Table 9). Specifically, the cities are concentrated in the provincial capital in the lower, upper and middle reaches. The higher closeness centrality in the lower reaches suggests that they should associate with other cities through the inherent connection of urban innovation elements at a faster rate. It seems clear that the closeness centrality in the upper reaches is lower than that in the lower and middle reaches, such as Guiyang and Kunming. In other words, when regarding Guiyang and Kunming as the core of urban network, the urban innovation level of the upper reaches is weak and the urban green development level is slow. 
Table 9

The centrality characteristics of spatial innovation correlation network.

\begin{tabular}{|c|c|c|c|c|c|c|c|c|c|c|c|}
\hline ID & $\begin{array}{l}\text { Prefecture } \\
\text { level city }\end{array}$ & $\begin{array}{l}\text { Degree } \\
\text { centrality }\end{array}$ & Sort & $\begin{array}{l}\text { Closeness } \\
\text { centrality }\end{array}$ & Sort & ID & $\begin{array}{l}\text { Prefecture } \\
\text { level city }\end{array}$ & $\begin{array}{l}\text { Degree } \\
\text { centrality }\end{array}$ & Sort & $\begin{array}{l}\text { Closeness } \\
\text { centrality }\end{array}$ & Sort \\
\hline 1 & Shanghai & 86.916 & 1 & 6.667 & 1 & 55 & Shiyan & 76.636 & 53 & 6.621 & 53 \\
\hline 2 & Nanjing & 86.916 & 2 & 6.667 & 2 & 56 & Yichang & 85.047 & 39 & 6.658 & 39 \\
\hline 3 & Wuxi & 86.916 & 3 & 6.667 & 3 & 57 & Xiangfan & 71.028 & 60 & 6.597 & 60 \\
\hline 4 & Xuzhou & 84.112 & 42 & 6.654 & 42 & 58 & Ezhou & 60.748 & 65 & 6.552 & 65 \\
\hline 5 & Changzhou & 86.916 & 4 & 6.667 & 4 & 59 & Jingmen & 71.963 & 58 & 6.601 & 58 \\
\hline 6 & Suzhou & 86.916 & 5 & 6.667 & 5 & 60 & Xiaogan & 71.963 & 59 & 6.601 & 59 \\
\hline 7 & Nantong & 86.916 & 6 & 6.667 & 6 & 61 & Jingzhou & 59.813 & 67 & 6.548 & 67 \\
\hline 8 & Lianyungang & 84.112 & 43 & 6.654 & 43 & 62 & Huanggang & 49.533 & 83 & 6.505 & 83 \\
\hline 9 & Huaian & 85.981 & 22 & 6.663 & 22 & 63 & Xianning & 69.159 & 62 & 6.589 & 62 \\
\hline 10 & Yencheng & 85.981 & 23 & 6.663 & 23 & 64 & Suizhou & 0 & 101 & 0 & 101 \\
\hline 11 & Yangzhou & 86.916 & 7 & 6.667 & 7 & 65 & Changsha & 85.981 & 33 & 6.663 & 33 \\
\hline 12 & Zhenjiang & 86.916 & 8 & 6.667 & 8 & 66 & Zhuzhou & 85.047 & 40 & 6.658 & 40 \\
\hline 13 & Taizhou & 86.916 & 9 & 6.667 & 9 & 67 & Xiangtan & 84.112 & 44 & 6.654 & 44 \\
\hline 14 & Suqian & 85.047 & 37 & 6.658 & 37 & 68 & Hengyang & 60.748 & 66 & 6.552 & 66 \\
\hline 15 & Hangzhou & 86.916 & 10 & 6.667 & 10 & 69 & Shaoyang & 46.729 & 84 & 6.493 & 84 \\
\hline 16 & Ningbo & 86.916 & 11 & 6.667 & 11 & 70 & Yueyang & 58.879 & 71 & 6.544 & 71 \\
\hline 17 & Wenzhou & 86.916 & 12 & 6.667 & 12 & 71 & Changde & 55.14 & 78 & 6.528 & 78 \\
\hline 18 & Jiaxing & 86.916 & 13 & 6.667 & 13 & 72 & Zhangjiajie & 0 & 102 & 0 & 102 \\
\hline 19 & Huzhou & 86.916 & 14 & 6.667 & 14 & 73 & Yiyang & 66.355 & 63 & 6.577 & 63 \\
\hline 20 & Shaoxing & 86.916 & 15 & 6.667 & 15 & 74 & Chenzhou & 53.271 & 79 & 6.52 & 79 \\
\hline 21 & Jinhua & 85.981 & 24 & 6.663 & 24 & 75 & Yongzhou & 46.729 & 85 & 6.493 & 85 \\
\hline 22 & Quzhou & 85.981 & 25 & 6.663 & 25 & 76 & Huaihua & 41.121 & 89 & 6.469 & 89 \\
\hline 23 & Zhoushan & 0 & 95 & 0 & 95 & 77 & Loudi & 56.075 & 77 & 6.532 & 77 \\
\hline 24 & Taizhou & 86.916 & 16 & 6.667 & 16 & 78 & Chongqing & 0 & 103 & 0 & 103 \\
\hline 25 & Lishui & 85.981 & 26 & 6.663 & 26 & 79 & Chengdu & 86.916 & 21 & 6.667 & 21 \\
\hline 26 & Hefei & 86.916 & 17 & 6.667 & 17 & 80 & Zigong & 70.093 & 61 & 6.593 & 61 \\
\hline 27 & Wuhu & 86.916 & 18 & 6.667 & 18 & 81 & Luzhou & 57.944 & 74 & 6.54 & 74 \\
\hline 28 & Bengbu & 85.981 & 27 & 6.663 & 27 & 82 & Panzhihua & 85.981 & 34 & 6.663 & 34 \\
\hline 29 & Huainan & 81.308 & 45 & 6.642 & 45 & 83 & Deyang & 79.439 & 50 & 6.634 & 50 \\
\hline 30 & Maanshan & 86.916 & 19 & 6.667 & 19 & 84 & Mianyang & 85.047 & 41 & 6.658 & 41 \\
\hline 31 & Huaibei & 85.047 & 38 & 6.658 & 38 & 85 & Guangyuan & 57.944 & 75 & 6.54 & 75 \\
\hline 32 & Tongling & 0 & 96 & 0 & 96 & 86 & Suining & 59.813 & 68 & 6.548 & 68 \\
\hline
\end{tabular}




\begin{tabular}{|c|c|c|c|c|c|c|c|c|c|c|c|}
\hline ID & $\begin{array}{l}\text { Prefecture } \\
\text { level city }\end{array}$ & $\begin{array}{l}\text { Degree } \\
\text { centrality }\end{array}$ & Sort & $\begin{array}{l}\text { Closeness } \\
\text { centrality }\end{array}$ & Sort & ID & $\begin{array}{l}\text { Prefecture } \\
\text { level city }\end{array}$ & $\begin{array}{l}\text { Degree } \\
\text { centrality }\end{array}$ & Sort & $\begin{array}{l}\text { Closeness } \\
\text { centrality }\end{array}$ & Sort \\
\hline 33 & Anqing & 85.981 & 28 & 6.663 & 28 & 87 & Neijiang & 50.467 & 82 & 6.509 & 82 \\
\hline 34 & Huangshan & 0 & 97 & 0 & 97 & 88 & Leshan & 59.813 & 69 & 6.548 & 69 \\
\hline 35 & Chuzhou & 85.981 & 29 & 6.663 & 29 & 89 & Nanchong & 42.991 & 87 & 6.477 & 87 \\
\hline 36 & Fuyang & 75.701 & 54 & 6.617 & 54 & 90 & Meishan & 53.271 & 80 & 6.52 & 80 \\
\hline 37 & Suzhou & 58.879 & 70 & 6.544 & 70 & 91 & Yibin & 58.879 & 72 & 6.544 & 72 \\
\hline 38 & Lu'an & 81.308 & 46 & 6.642 & 46 & 92 & Guang'an & 42.991 & 88 & 6.477 & 88 \\
\hline 39 & Mizhou & 0 & 98 & 0 & 98 & 93 & Dazhou & 41.121 & 90 & 6.469 & 90 \\
\hline 40 & Chizhou & 0 & 99 & 0 & 99 & 94 & Ya'an & 0 & 104 & 0 & 104 \\
\hline 41 & Xuancheng & 85.981 & 30 & 6.663 & 30 & 95 & Bazhong & 33.645 & 93 & 6.438 & 93 \\
\hline 42 & Nanchang & 85.981 & 31 & 6.663 & 31 & 96 & Ziyang & 57.009 & 76 & 6.536 & 76 \\
\hline 43 & Jingdezhen & 79.439 & 47 & 6.634 & 47 & 97 & Guiyang & 85.981 & 35 & 6.663 & 35 \\
\hline 44 & Pingxiang & 79.439 & 48 & 6.634 & 48 & 98 & Liupanshui & 46.729 & 86 & 6.493 & 86 \\
\hline 45 & Jiujiang & 76.636 & 51 & 6.621 & 51 & 99 & Zunyi & 63.551 & 64 & 6.564 & 64 \\
\hline 46 & Xinyu & 85.981 & 32 & 6.663 & 32 & 100 & Anshun & 0 & 105 & 0 & 105 \\
\hline 47 & Yingtan & 0 & 100 & 0 & 100 & 101 & Kunming & 85.981 & 36 & 6.663 & 36 \\
\hline 48 & Ganzhou & 73.832 & 55 & 6.609 & 55 & 102 & Qujing & 41.121 & 91 & 6.469 & 91 \\
\hline 49 & Ji'an & 76.636 & 52 & 6.621 & 52 & 103 & Yuxi & 73.832 & 57 & 6.609 & 57 \\
\hline 50 & Yichun & 57.944 & 73 & 6.54 & 73 & 104 & Baoshan & 0 & 106 & 0 & 106 \\
\hline 51 & Fuzhou & 73.832 & 56 & 6.609 & 56 & 105 & Zhaotong & 19.626 & 94 & 6.38 & 94 \\
\hline 52 & Shangrao & 50.467 & 81 & 6.509 & 81 & 106 & Lijiang & 0 & 107 & 0 & 107 \\
\hline 53 & Wuhan & 86.916 & 20 & 6.667 & 20 & 107 & Simao & 38.318 & 92 & 6.457 & 92 \\
\hline 54 & Huangshi & 79.439 & 49 & 6.634 & 49 & 108 & Lincang & 0 & 108 & 0 & 108 \\
\hline
\end{tabular}

\subsection{On the whole network structure}

On the whole network structure, the urban green development and the network density at four scales are chosen as the explaining and explanatory variables in the OLS regression when in the natural logarithm transformation.

The whole spatial innovation correlation network structure gives a significant and positive effect to urban green development, which can be found in Table 10. The improvement of network density can effectively promote the urban green development level in YREB. Notable, the network density of YREB's urban innovation has a positive impact on the urban green development, which is more significant in middle reaches than in lower and upper reaches of YREB. Therefore, it is necessary to continuously strengthen the spatial connection between the lower reaches and the upper reaches by increasing some necessary lines and reducing some redundant lines from associated innovation institutional reforms. 
OLS regression results of the whole network structure.

\begin{tabular}{|c|c|c|c|c|}
\hline & (1) & (2) & (3) & (4) \\
\hline & YREB & $\begin{array}{l}\text { Lower reaches of } \\
\text { YREB }\end{array}$ & $\begin{array}{l}\text { Middle reaches of } \\
\text { YREB }\end{array}$ & $\begin{array}{l}\text { Upper reaches of } \\
\text { YREB }\end{array}$ \\
\hline Variable & UGD & UGD & UGD & UGD \\
\hline Network density (YREB) & $0.184^{\star \star \star}$ & & & \\
\hline & $(0.0172)$ & & & \\
\hline Network density (Lower reaches) & & $0.944 * \star \star$ & & \\
\hline & & $(0.126)$ & & \\
\hline $\begin{array}{l}\text { Network density (Middle } \\
\text { reaches) }\end{array}$ & & & $1.377^{\star \star \star}$ & \\
\hline & & & $(0.138)$ & \\
\hline Network density (Upper reaches) & & & & $0.950 * \star \star$ \\
\hline & & & & $(0.173)$ \\
\hline C & 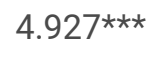 & $6.072^{\star \star \star}$ & $6.848 * \star \star$ & $6.539 * \star \star$ \\
\hline & $(0.0295)$ & $(0.189)$ & $(0.220)$ & $(0.343)$ \\
\hline Observations & 11 & 11 & 11 & 11 \\
\hline $\mathrm{R}^{2}$ & 0.927 & 0.862 & 0.917 & 0.769 \\
\hline
\end{tabular}

\subsection{On the individual network structure}

This study takes the green development level of 108 cities in YREB as an explanatory variable to analyze the impact of individual innovation network structure on urban green development. The regression coefficient of degree centrality is 0.612 , indicating that cities with high degree centrality have a stronger leading role rather than other cities inside the spatial innovation correlation network. Under the circumstance, government should pay more attention to these cities to promote the whole urban green development level of YREB. However, there are still plenty of cities with low degree centrality and low green development level that need to strengthen the innovation connection with the lower reaches. For example, the talents, technologies and funds in the lower reaches of YREB should be associated with the upper and middle reaches. What's more, government should be encouraged to reduce the unemployment rate, increase the urbanization rate and increase the science and education expenditure, and so on. 
Table 11

Impact of degree centrality on urban green development.

\begin{tabular}{|c|c|c|c|c|c|c|}
\hline & (1) & (2) & (3) & (4) & (5) & (6) \\
\hline Variable & UGD & UGD & UGD & UGD & UGD & UGD \\
\hline \multirow[t]{2}{*}{ Degree centrality } & $0.612^{\star \star \star}$ & 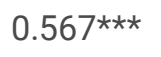 & $0.514^{\star \star \star}$ & $0.508^{\star \star \star}$ & $0.488^{\star \star \star}$ & $0.411^{\star \star \star}$ \\
\hline & $(0.0377)$ & $(0.0302)$ & $(0.0358)$ & $(0.0358)$ & $(0.0380)$ & $(0.0448)$ \\
\hline \multirow[t]{2}{*}{ FDI } & & $-4.918 * \star \star$ & 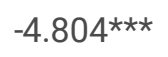 & $-4.823 * \star \star$ & $-4.892^{\star \star \star}$ & $-4.458 * \star \star$ \\
\hline & & (1.193) & $(1.175)$ & (1.165) & $(1.172)$ & $(0.986)$ \\
\hline \multirow[t]{2}{*}{ ER } & & & $1.737 * \star \star$ & $1.716^{\star \star \star}$ & $1.725^{\star \star \star}$ & $1.506^{\star \star}$ \\
\hline & & & $(0.622)$ & $(0.619)$ & $(0.618)$ & $(0.619)$ \\
\hline \multirow[t]{2}{*}{ UNE } & & & & $-0.260 *$ & $-0.259 *$ & $-0.213^{\star}$ \\
\hline & & & & $(0.150)$ & $(0.150)$ & $(0.124)$ \\
\hline \multirow[t]{2}{*}{ Urban } & & & & & $1.945^{\star \star}$ & $2.492^{\star \star \star}$ \\
\hline & & & & & $(0.798)$ & $(0.781)$ \\
\hline \multirow[t]{2}{*}{ TE } & & & & & & $5.079 * \star \star$ \\
\hline & & & & & & $(1.780)$ \\
\hline \multirow[t]{2}{*}{ C } & $79.65^{\star \star \star}$ & $92.31 * \star \star$ & 85.68 *** & 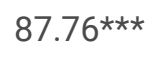 & $77.12^{\star \star \star}$ & $68.02^{\star \star \star}$ \\
\hline & $(1.256)$ & $(2.753)$ & $(3.637)$ & (3.986) & (6.385) & $(6.306)$ \\
\hline $\mathrm{R}^{2}$ & 0.476 & 0.515 & 0.535 & 0.537 & 0.539 & 0.570 \\
\hline $\mathrm{N}$ & 108 & 108 & 108 & 108 & 108 & 108 \\
\hline
\end{tabular}

The regression coefficient of closeness centrality is 8.119 , presenting that in the spatial innovation correlation network. Cities with high closeness centrality have the comparative advantages with other cities. The cities may control and guide the flow direction of urban innovation elements in more targeted manner, which can strengthen the "spatial spillover" effect on other cities inside the spatial innovation correlation network. On the other hand, cities with low closeness centrality and low urban green development level have to be enhance the potential to obtain innovation profitability inside the network. To sum up, cities with high closeness centrality and high urban green development level should be encouraged to guide and transfer the specific innovation elements to motivate urban green development from the perspective of network. 
Table 12

Impact of closeness centrality on urban green development.

\begin{tabular}{|c|c|c|c|c|c|c|}
\hline & (7) & (8) & (9) & (10) & (11) & (12) \\
\hline Variable & UGD & UGD & UGD & UGD & UGD & UGD \\
\hline \multirow[t]{2}{*}{ Closeness centrality } & $8.119 * \star \star$ & $7.357 * \star \star$ & $6.744^{\star \star \star}$ & $6.701^{\star \star \star}$ & $6.247^{\star \star \star}$ & $5.413^{\star \star \star}$ \\
\hline & $(0.584)$ & $(0.480)$ & $(0.532)$ & $(0.527)$ & $(0.559)$ & $(0.613)$ \\
\hline \multirow[t]{2}{*}{ FDI } & & $-5.068^{\star \star \star}$ & $-4.938 * \star \star$ & $-4.948 * \star \star$ & $-5.088 * \star \star$ & $-4.782^{\star \star \star}$ \\
\hline & & $(1.228)$ & (1.198) & (1.193) & $(1.217)$ & $(1.049)$ \\
\hline \multirow[t]{2}{*}{ ER } & & & $1.797 \star \star \star$ & 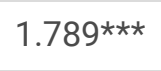 & 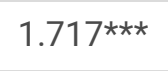 & $1.379 * \star$ \\
\hline & & & $(0.560)$ & $(0.564)$ & $(0.553)$ & $(0.565)$ \\
\hline \multirow[t]{2}{*}{ UNE } & & & & -0.145 & -0.141 & -0.115 \\
\hline & & & & $(0.0947)$ & $(0.0908)$ & $(0.0732)$ \\
\hline \multirow[t]{2}{*}{ Urban } & & & & & $4.017^{\star \star \star}$ & $4.251^{\star \star \star}$ \\
\hline & & & & & $(0.975)$ & $(0.920)$ \\
\hline \multirow[t]{2}{*}{ TE } & & & & & & $4.395^{\star \star}$ \\
\hline & & & & & & $(1.834)$ \\
\hline \multirow[t]{2}{*}{ C } & $68.65^{\star \star \star}$ & $85.06^{\star \star \star}$ & $78.79 * \star \star$ & $79.98 * \star \star$ & $58.34^{\star \star \star}$ & $53.63^{\star \star \star}$ \\
\hline & $(2.873)$ & $(3.750)$ & $(4.168)$ & (4.499) & $(6.860)$ & $(6.236)$ \\
\hline $\mathrm{R}^{2}$ & 0.501 & 0.545 & 0.564 & 0.565 & 0.574 & 0.600 \\
\hline$N$ & 100 & 100 & 100 & 100 & 100 & 100 \\
\hline
\end{tabular}

\section{Discussion And Conclusions}

\subsection{Main achievements}

As a typical region moving forward on green development demonstration belt, the Yangtze River Economic Belt is a valuable subject to explore whether and how urban innovation offers a sound solution to the dilemma of urban green development. Uncovering the influence path can help mitigate the detrimental effect on natural resources and ecological environment for the green demonstration belt. This study estimated the general trend of urban green development and the topological characteristic of spatial correlation network of innovation for YREB during period 2006-2016. It further investigated the specific impact of urban innovation on urban green development through uniting the government-scale, enterprise-scale and spatial correlation network. The research framework can provide the practical policy implications for the study area, as well as a theory framework for clarifying the interaction between urban innovation and green development.

Our research findings indicated that the urban innovation in YREB promote the urban green development. However, there is obvious heterogeneity in the interaction of innovation and green development for various cities. For instance, it is more apparent in the middle reaches than in the upper and lower reaches. Moreover, the government-scale and enterprise-scale are two important moderating factors between urban innovation and urban green development. The coefficients of urban innovation are all significant in the cities with various government scales and enterprise scales, which means the innovation-driven urban green development is effective in the cities with any scale. 
The study further illustrated that the optimization of spatial correlation network of innovation can also promote the green development of all cities in YREB. Inside the spatial correlation network, the increase of network density can well improve the urban green development level. Moreover, the city's central position in the spatial innovation correlation network has also a significant role in promoting the urban green development inside YREB. In other words, if cities play a crucial role in the spatial innovation correlation network, these cities will have a large spillover effect on the surrounding areas, which is conducive to innovation-driven urban green development.

\subsection{Policy implications and limitations}

The central government of China has put forward the innovation-driven development policy, emphasizing that urban innovation can promote urban development continuously. A more flexible implementation of plenty of policies would promote technology innovation, further facilitate the green development and enhance the environmental performance, in spite of the negative effects from some specific environmental policies (Albrizio et al., 2017). As a matter of fact, government often launch some adaptive and appropriate programs to promote the technology innovation of enterprises, such as providing some subsidies of pollution mitigation, setting some targets of environmental supervision, granting the green credits and collecting the emission taxes, and so on.

From the view of regional disparity, furthermore, it will be critical to avoid a "one-size-fits all" policy approach, both across technologies and across cities. Government should expand the functional scope and strengthen the intervention when focusing on some cities with lower green development level and smaller scale. It is also suggested that government should initiate and launch some preferential policies and projects to drive the cities with small enterprise-scale. For example, some financial subsidies can help reduce the cost and risk of urban innovation (Huang et al, 2019). In terms of spatial correlation network, the network density of urban innovation has been tied to the enhancement of urban green development, which is more significant in middle reaches than in lower and upper reaches of YREB. Due to the motivated effect from network density and network centrality, the cities in middle reaches have reason to act for themselves through attracting adequate talents and strengthen the connections among the three reaches. In other words, it is profitable for deepening the network effect and talent flow effect of between cities, promoting the formation of coordination mechanism of green innovation among cities. One important issue, especially for some cities with low network density, centrality and green development, is integrating technical and industry expertise into government decision-making. Some cities and their industries articulate its performance needs, finds supporting funding, and funds academics to develop new or advanced technological technology to achieve the green development goals.

However, because of the restriction of data availability, it is hard to choose indicators that can cover all aspects of the compound urban green development index. We have the limitation that the study puts emphasis only on the past period and does not cover dynamic predictions, yet green development research would be better served by a long-term perspective. The urban green development is brought about by multiple intertwined factors, so we hope to make deeper explorations of the motivated determinants and reveal the interactions among different determinants. Indeed, inquiring into whether and how urban innovation offers a sound solution to the dilemma of urban green development is just the precondition of achieving a regional sustainability transition, and the journey towards real sustainability has just begun.

\section{Declarations}

\section{Acknowledgments}

We are grateful for support from the fund projects: National Natural Science Foundation of China (72074107\&71603111), National statistical scientific research projects of China (2020LY062), and a Project Funded by the Priority Academic Program Development of Jiangsu Higher Education Institutions.

Ethics approval and consent to participate Not applicable.

Consent for publication Not applicable. 
Author contribution Z.N. conceptualized the idea. F. T., L. Y., and Z. L. wrote the first draft, and Z. N. reviewed the manuscript. All authors approved the manuscript.

Funding This research is supported by the National Natural Science Foundation of China (72074107\&71603111), National statistical scientific research projects of China (2020LY062).

Competing interests The authors declare no competing interests.

Availability of data and materials Not applicable.

\section{References}

1. Albrizio S, Kozluk T, Zipperer V (2017) Environmental policies and productivity growth: Evidence across industries and firms. Journal of Environmental Economics Management 81:209-226. doi: 10.1016/j.jeem.2016.06.002

2. Acemoglu D, Aghion P, Bursztyn L, Hemous D (2012) The Environment and Directed Technical Change. Am Econ Rev 102(1):131-166. doi: 10.2139/ssrn.1668575

3. Batabyal AA, Beladi H (2014) Innovation driven economic growth in multiple regions and taxation: a dynamic analysis. Int Reg Sci Rev 37(4):459-472. doi: 10.1177/0160017612462721

4. Beck T, Demirguc-Kunt A, Maksimovic V (2005) Financial and Legal Constraints to Growth: Does Firm Size Matter? Journal of Finance 60:137-177. doi: 10.2307/3694836

5. Bloom DE, Canning D, Fink G (2008) Urbanization and the Wealth of Nations. Science 319:772-775. doi: 10.1126/science. 1153057

6. Cao Y, Wan N, Zhang ZH, Zhou Q (2020) Linking environmental regulation and economic growth through technological innovation and resource consumption: Analysis of spatial interaction patterns of urban agglomerations. Ecol Ind 112(5):106062. doi: 10.1016/j.ecolind.2019.106062

7. Chaudhry IS, Ali S, Bhatti SH, Anser MK, Khan Al, Nazar R (2021) Dynamic common correlated effects of technological innovations and institutional performance on environmental quality: Evidence from East-Asia and Pacific countries. Environ Sci Policy 124:313-323. doi: 10.1016/j.envsci.2021.07.007

8. Cui BS, Zhang ZhangQJ, Liu KJ, Zhang XH (2011) Analyzing trophic transfer of heavy metals for food webs in the newlyformed wetlands of the Yellow River Delta, China. Environ Pollut 159:1297-1306

9. Cumming D (2007) Government policy towards entrepreneurial finance: Innovation investment funds. J Bus Ventur 22(2):193-235. doi: 10.1016/j.jbusvent.2005.12.002

10. Dai X, Sun Z (2021) Does firm innovation improve aggregate industry productivity? Evidence from Chinese manufacturing firms. Struct Change Econ Dyn 56:1-9. doi: 10.1016/j.strueco.2020.09.005

11. Fang DL, Chen B, Hubacek K, Ni RJ, Chen LL, Feng KS, Lin JT (2019) Clean air for some: Unintended spillover effects of regional air pollution policies. Sci Adv. doi: 10.1126/sciadv.aav4707. ,5,eaav4707

12. Feng J, Yuan J (2016) Effect of technology innovation and spillovers on the carbon intensity of human well-being. SpringerPlus 5(1):346. doi: 10.1186/s40064-016-1984-0

13. Glemarec Y, Oliveira JAP (2012) The role of the visible hand of public institutions in creating a sustainable future. Public Administration and Development 32(3):200-214. doi: 10.1002/pad.1631

14. Gunderson R, Yun S-J (2017) South Korean green growth and the Jevons paradox: An assessment with democratic and degrowth policy recommendations. J Clean Prod 144(15):239-247. doi: 10.1016/j.jclepro.2017.01.006

15. Guo J, Zhao M, Wu X, Shi B et al (2021) Study on the distribution of PM emission rights in various provinces of China based on a new efficiency and equity two-objective DEA model. Ecol Econ 183:106956. doi: 10.1016/j.ecolecon.2021.106956

16. Hansen BE (1999) Threshold Effects in Non-dynamic Panels: Estimation, Testing and Inference. J Econ 93(2):345-368. doi: 10.1016/S0304-4076(99)00025-1 
17. Hippel EV, Krogh GV (2006) Free revealing and the private-collective model for innovation incentives. Social Science Electronic Publishing 36(3):295-306. doi: 10.1111/j.1467-9310.2006.00435.x

18. Huang Z, Liao G, Li Z (2019) Loaning scale and government subsidy for promoting green innovation. Technol Forecast Soc Chang 144:148-156. doi: 10.1016/j.techfore.2019.04.023

19. Jin P, Peng C, Song M (2019) Macroeconomic uncertainty, high-level innovation, and urban green development performance in China. China Econ Rev 55:1-18. doi: 10.1016/j.chieco.2019.02.008

20. Khanna R, Sharma C (2021) Do technological investments promote manufacturing productivity? A firm-level analysis for India. Econ Model 105:105672. doi: 10.1016/j.econmod.2021.105672

21. Li P, Lin Z, Du H, Feng T, Zuo J (2021) Do environmental taxes reduce air pollution? Evidence from fossil-fuel power plants in China. J Environ Manage 295:113112. doi: 10.1016/j.jenvman.2021.113112

22. Li W, Wang J, Chen R, Xi Y, Liu SQ, Wu F, Masoud M, Wu X (2019) Innovation-driven industrial green development: The moderating role of regional factors. Journal of Cleaner Production 222:344-354. doi: 10.1016/j.jclepro.2019.03.027

23. Liu X, Zhang X (2021) Industrial agglomeration, technological innovation and carbon productivity: Evidence from China. Resour Conserv Recycl 166:105330. doi: 10.1016/j.resconrec.2020.105330

24. Lin B, Benjamin NI (2017) Green development determinants in China: a non-radial quantile outlook. J Clean Prod 162:764775. doi: 10.1016/j.jclepro.2017.06.062

25. Marchi VD (2012) Environmental innovation and R\&D cooperation: Empirical evidence from Spanish manufacturing firms. Res Policy 41(3):614-623. doi: 10.1016/j.respol.2011.10.002

26. Martinelli A, Midttun A (2010) Globalization and governance for sustainability. Corporate Governance International Journal of Business in Society 10(1):6-17. doi: 10.1108/14720701011021076

27. Mei L, Shao W (2016) The effect of firm size on regional innovation efficiency in China. Modern Economy 7(10):10351049. doi: $10.4236 /$ me.2016.710106

28. Ouyang Z, Song C, Zheng H, Polasky S, Xiao Y et al (2020) Using gross ecosystem product (GEP) to value nature in decision making. Proceedings of the National Academy of Sciences, 117(25):201911439. doi: 10.1073/pnas.1911439117

29. Pujari DD (2010) Mainstreaming Green Product Innovation: Why and How Companies Integrate. Environmental Sustainability. J Bus Ethics 95(3):471-486. doi: 10.1007/s10551-010-0434-0

30. Shao SA, Luan RR, Yang ZB, Li CY (2016) Does directed technological change get greener: empirical evidence from Shanghai's industrial green development transformation. Ecol Ind 69:758-770. doi: 10.1016/j.ecolind.2016.04.050

31. Snieska V, Valodkiene G (2015) Impact of innovations upon economic growth during recession. Technological \& Economic Development of Economy 21(4):626-642. doi: 10.3846/20294913.2015.1055615

32. Tan F, Jiang X, Lu Z (2017) Some enlightenment on stakeholder engagement: An inquiry into sustainable development disparity and its drivers in China's two leading economic zones. Sustain Dev 25(6):671-685. doi: 10.1002/sd.1686

33. Tan F, Lu Z (2015) Interaction characteristics and development pattern of sustainability system in BHR (Bohai Rim) and YRD (Yangtze River) regions. Ecological Informatics 30:29-39. doi: 10.1016/j.ecoinf.2015.09.008

34. Tan F, Lu Z (2019) The impact of urban compactness on urban sustainable development in China: The case of Nanjing. Sustain Dev 27:270-280. doi: 10.1002/sd.1874

35. Tang M, Li Z, Hu F, Wu B, Zhang R (2021) Market failure, tradable discharge permit, and pollution reduction: Evidence from industrial firms in China. Ecol Econ 189:107180. doi: 10.1007/s10668-021-01381-5

36. Villegas-Palacio C, Coria J (2010) On the interaction between imperfect compliance and technology adoption: taxes versus tradable emissions permits. J Regul Econ 38(3):274-291. doi: 10.1007/s11149-010-9125-0

37. Wang C, Liao H, Pan S-Y, Zhao L-T, Wei Y-M (2014) The fluctuations of China's energy intensity: biased technical change. Appl Energy 135:407-414. doi: 10.1016/j.apenergy.2014.06.088

38. Wang H, Qi S, Zhou C, Zhou J, Huang X (2021) Green credit policy, government behavior and green innovation quality of enterprises. J Clean Prod. 129834doi: 10.1016/j.jclepro.2021.129834

Page $21 / 23$ 
39. Wang M, Pang S, Hmani I, Hmani I, Li C, He Z (2019) Towards sustainable development: How does technological innovation drive the increase in green total factor productivity? Sustainable Development 29:217-227. doi: 10.1002/sd.2142

40. Wang Q, Qu J, Wang B, Wang P, Yang T (2019) Green technology innovation development in China in 1990-2015. Sci Total Environ 696:134008. doi: 10.1016/j.scitotenv.2019.134008

41. Wang SJ, Ma H, Zhao YB (2014) Exploring the relationship between urbanization and the eco-environment -a case study of Beijing-Tianjin-Hebei region. Ecol Ind 45:171-183. doi: 10.1016/j.ecolind.2014.04.006

42. Wei Y, Li Y, Liu X, Wu M (2020) Sustainable development and green gross domestic product assessments in megacities based on the emergy analysis method-A case study of Wuhan. Sustain Dev 28:294-307. doi: 10.1002/sd.2003

43. Weng Q, Qin Q, Li L (2020) A comprehensive evaluation paradigm for regional green development based on "Five-Circle Model": A case study from Beijing-Tianjin-Hebei. J Clean Prod 277:124076. doi: 10.1016/j.jclepro.2020.124076

44. Yang XJ (2013) China's Rapid Urbanization. Science 342(18):310-311. doi: 10.1016/j.jclepro.2020.124076

45. Zhao J, Xi X, Na Q, Wang S, Kadry SN et al (2020) The technological innovation of hybrid and plug-in electric vehicles for environment carbon pollution control. Environ Impact Assess Rev 86:106506. doi: 10.1016/j.eiar.2020.106506

46. Zhao P, Ang BW, Han JY (2010) Total factor carbon emission performance: a Malmquist index analysis. Energy Econ 32(1):194-201. doi: 10.1016/j.eneco.2009.10.003

47. Zhu Y, Wang Z, Yang J, Zhu L (2020) Does renewable energy technological innovation control China's air pollution? A spatial analysis. J Clean Prod 250:119515. doi: 10.1016/j.jclepro.2019.119515

\section{Figures}
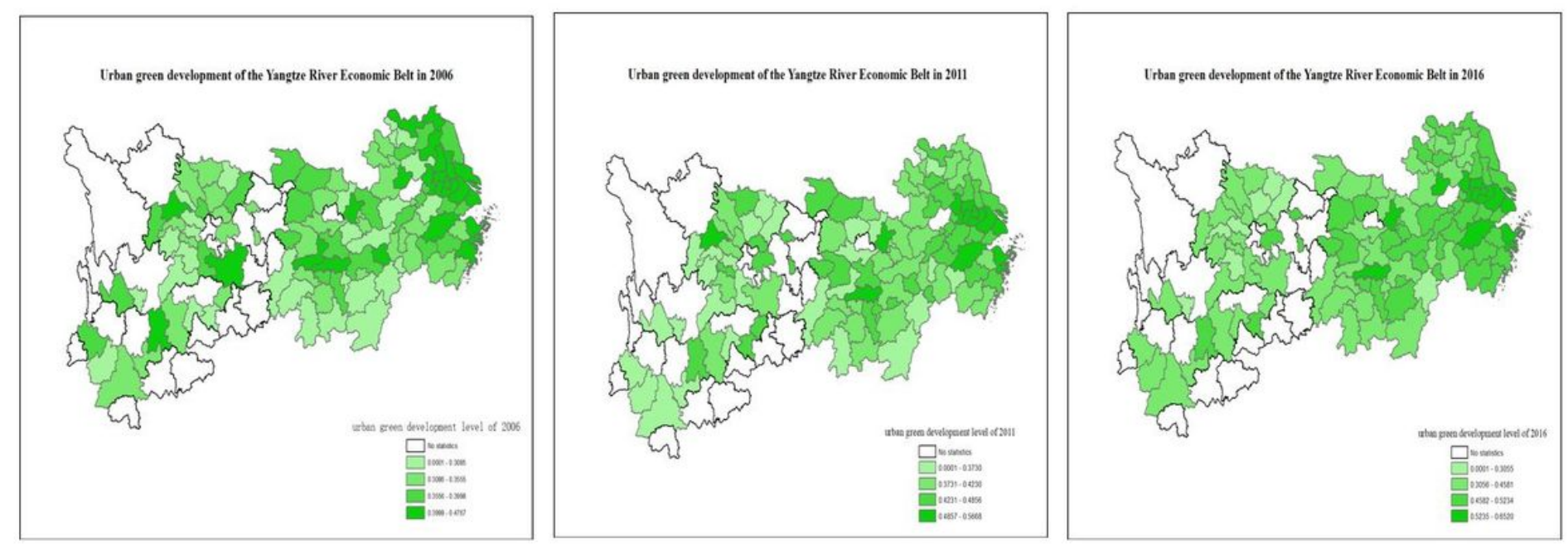

\section{Figure 1}

Urban green development level of the Yangtze River Economic Belt in 2006, 2011, 2016. 


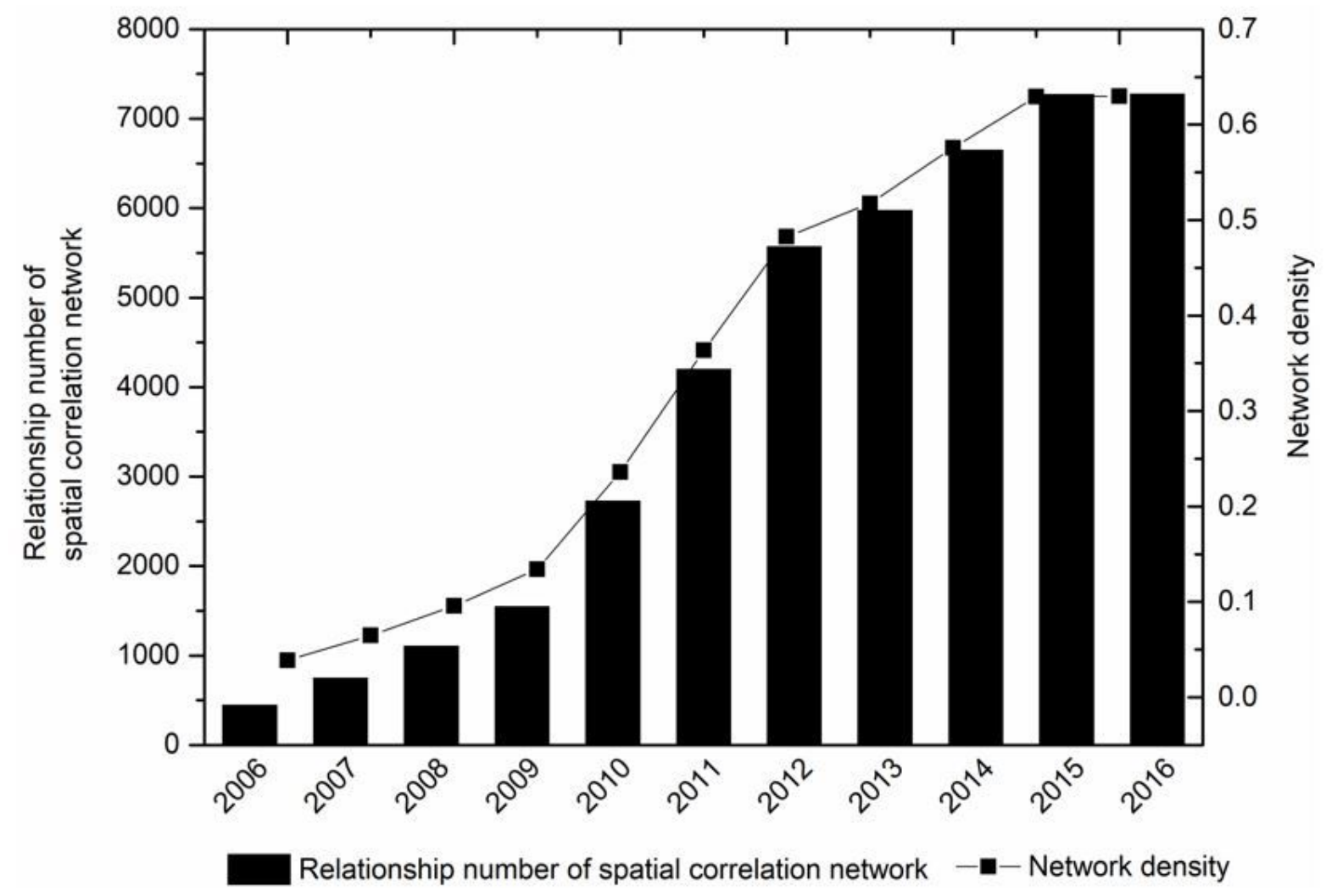

Figure 2

Relationship number and network density of the spatial correlation network of urban innovation. 